\title{
Hermeneutic Islamic Feminism: An Epistemiological Intellectual Approach
}

\author{
Sana Kadhim Qati \\ Assistant Professor of Political Thought, College of Political Science, University of Baghdad, Iraq
}

\begin{abstract}
.
With the contemporary changes in the Islamic political intellectual arena, the phenomenon of Islamic feminism had a clear impact on it. opening a field for discussion. Feminist research focuses on how to produce knowledge and spread an alternative culture about women in general, that is, re-reading cultural history to form awareness to support the roles of women in confronting Prevailing misconceptions. Among the principles established in feminist research are almost two main issues: building alternative knowledge, and achieving social change, that is, attempts to review prevailing knowledge, that is to review the complex philosophical, social, cultural, and political structures of the sexual differences between men and women, and to the disclosure of the reasons for the absence and exclusion of women within the framework of power relations prevailing in society, so that feminist research contributes to building alternative knowledge that can affect a clear social change towards achieving social justice for women by confronting the intellectual, social and ideological structures based on the oppression of women and that entrench prejudices based on gender. Islamic feminism relies on the necessity of having multiple connotations, one of which is awareness of the inequality in social relations between men and women with the presence of the will to change this asymmetry towards equality. As well as a sign of protest against the conditions of women's subordination and subordination and the oppression inflicted on them by the patriarchal society. In addition to the critical significance, in not ceasing to thinking and criticizing everything that might highlight the discrimination between the sexes, so that unequal power prevails in bilateral relations with the authority of men in exchange for the subordination of women. The importance of this topic stems from the necessity to add it to academic studies within the framework of gender studies in the Arab-Islamic world. Our research looks at a set of important points, including 1- How did interpretive Islamic feminism become a research method that criticizes the traditional legacies in the societies of the Arab and Islamic world? 2What are the steps of interpretive Islamic feminism to formulate an Islamic epistemological theory that addresses women's issues? 3- What are the methodological tools of Islamic feminism to be able to extract the rights of stolen women? 4- What are the most prominent intellectual principles of Islamic feminism, which constituted basic issues for her in formulating her epistemological theory?
\end{abstract}

Keywords: feminism, Hermeneutical, Islamic feminism, Cognitive theory

\section{1-Introduction}

Islamic feminism emerged with the emergence of the reformist Islamic trend, which began to look at women through knowledge to change the traditional view of societies that were built based on the existence of the male system and thus destroy the productive structures of a culture of discrimination. This is what Al-Mahrizi summed up by saying that the proponents of the 


\section{2nd Global Conference on Women's Studies}

10-12 June 2021

Berlin - Germany

renewed religious trend see "that religious issues that are related to the position of women in religious texts are a reflection of the lifestyle and culture of the era of the revelation, which is different to the divine essence in these texts."(Mahdi Mahrizi -2017).

Islamic feminism emerged for multiple reasons and factors some internal and others external, based on various cultural, social, ideological, and political considerations, most notably the following:

1- The importance of the issue of human rights in global thought, by the international changes witnessed in the last decade of the last century, to qualify women's issues to enter the political intellectual arena, and to inaugurate a new phase that touched the need for serious solutions to it, especially in light of the terms of economic empowerment and political empowerment, to become the issue of participation in the demand the Most powerful feminist.

2- To some extent, Islamic feminism, came as a reaction to Western feminism, which increased the feeling of alienation and dissatisfaction among a large number of non-Western women.

3- Reality and problems of women in the Arab and Islamic world that stemmed from the system of popular culture (cultural heritage) and official institutions (legislation), and women's sense of injustice and deprivation (especially in the issue of political rights) and violence directed at them in favor of systematic male discrimination, which established the idea of women's inferiority and tyranny of the authoritarian view of their potentials and capabilities, in contrast to the supremacy of male values established by the inherited historical social structures. (Amani Saleh-2000)

4- The sovereignty of patriarchal regimes that seeking to establish biased structures, and unilaterally interpret the structure of social relations, and work to suppress interactive social structures which have led to the absence of justice and the practice of policies of harassment against women at all levels.

5- The effect of the colonial phase on the emergence of national liberation movements, with which women began to link the cause of the nation's liberation to the emancipation of women from societal injustice. as many women involved in the national movements against the occupation authorities, until they linked their hopes for achieving gender justice with the struggle for independence and liberation the

the the 6- The increasing feminist affiliation to the fields of knowledge, especially religious knowledge, which perceives the need for renewal in jurisprudence from a feminist perspective as a result of the large gap between the established and legally guaranteed rights of women in the field of public policies and law, and the reality of Muslim women is a testament to the failure to download Islamic verses and rulings in it, with the rule of perception, Most of the contemporary Islamic heritage confirms that women are an imperfect and inferior being by nature, in addition to the religious thought that plays a fundamental role in drawing a negative image of women in the male and feminist human imagination alike, which has generated a renewed view by some Muslim writers to raise the issue of the necessity of reading the Quranic text with modern tools, until it brought about transformations in contemporary Islamic discourse and thought and its literature on the issue of women and moving from responding to suspicions to attempts to crystallize new formulas based on Islamic principles $r$ responding to the needs of the nation in the current era and line with the wave of change, reform, and renewal that includes its demands for change. The status of women and criticism of concepts, legacies, and traditions that hinder their effectiveness in the public sphere. (Zaki Al-Milad-2008)

7- A reaction to the discourse of the growing defensive Islamic trend that limited the issue of women to specific discussions such as (the rights and duties of Muslim women) or (Islam's honor to women), this speech that was devoted to a secondary status of women from a religious 


\section{2nd Global Conference on Women's Studies}

10-12 June 2021

Berlin - Germany

perspective, which led, then, to the consolidation of inequality Unknowingly between the sexes, in the name of preserving the Islamic cultural identity, which then also led to a change in the feminist mechanism from the position of defending Muslim women and their position in society, to the critical and progressive Islamic position towards women's liberation and improvement of their conditions from an Islamic modernizing perspective, (Asma Lamrabet2019)This is what the 1990 witnessed when new feminist propositions crystallized with it in order to rid women of negative societal restrictions, traditions and customs, especially in light of the widening circle of changes in relations and social awareness, which in turn led to confronting many previous beliefs about the issue of women. A new crisis and the work to confront these beliefs have led to the emergence of social movements, parties, associations.

8- A reaction to the spread of extremist fundamentalisms far removed from the issue of human rights, when it adopted violence as the only way to confront the other and work to eliminate it, with an emphasis on returning to the past with cases of fossilization that confiscate all human development, and it is a call to undermine modernity and its manifestations and ideologies, which increased The desire of women to confront them and adhere to their rights through a feminist movement that expresses the basic Islamic contents that affirm equality, justice and rights. (Amani Saleh-2002).

9- The growth of political Islam and its success in attracting women to sweep the public sphere, which highlighted a new generation of Islamic women distinguished by their extreme boldness and their sharp confrontational style, concerning looking at the role and position of women in Islamic countries, affirming the priority of standards established by the United Nations on human rights. Women are skeptics at the same time in the movement for the liberation of women with secular orientations that failed to address women's rights and activate their role in the public sphere. (Amal Garami-2015).

10- Limiting and marginalizing the role of women in political decision-making positions resulting from their oppression on a religious and social basis, the Islamists' domination of the official political scene (the new parliaments) and their negative attitude towards the participation of women in public life, which increased the confrontation of women and emphasized that they have an important role as citizens and have their right Contribute to building the nation.

11-Islamic feminismś association with the academic Knowledge aspect, with difference specialized fields of knowledge for those seeking to achieve the goals of Islamic feminism between Islamic religious disciplines, history, law, political science, literature, science and medical fields etc, which reflected the abundance and diversity of topics that addressed by Islamic feminism in dealing with women's issues, through vision of each of them by their specialization of knowledge. For example, the legal aspect of women's issues was dealt with by Aziza Al-Hibri, Ziba Mir Hosseini, and Naira Tawhidi, while Fatima Mernissi and Laila Ahmed focused on the intellectual side, while Rifaat Hassan, Amina Wadud and Asma Barlas focused their treatments on the religious side. Despite this diversity in the specialization of subjects, similar issues are often engaged in, all of which seem to be a matter of common interest, especially for those who study the issue of women in the Middle East.

\section{2- The foundations of hermeneutics feminism in formulating its an epistemological theory}

In agreement with Fahmi Jadaan (Fahmi Jadaan-2010), that interpretive Islamic feminism is one that can be aimed at being a true Islamic feminism worthy of the requirements of the current 


\section{2nd Global Conference on Women's Studies}

10-12 June 2021

Berlin - Germany

era, we have to delve into the rationale for this (hermeneutical) feminism with an outline of its most important intellectual basis in attempts to build and develop the field of research The new Islamic feminist, and the establishment of an Islamic heritage that is different from the patriarchal discourse that is dominant in most Arab Islamic societies, that is, in other words, the consolidation of serious attempts to build and establish a field of knowledge concerned with women's issues away from the method of advocacy in defending the existence of women, which was dominated by a critical character and controversial tendency. Accordingly, it is possible to put forward a number of intellectual premises for the interpretive Islamic feminism, which formed fundamental issues for which it stood for a long time to prove the rights of women that were confiscated on discriminatory rather than legitimate grounds, the most important of which are:

\subsection{Persecution}

which is the most prominent issue from which interpretive Islamic feminism started ideologically, demanding that it be lifted from women by the male authority that was and still is oppressing. The hermeneutic Islamic feminism uses the case of ijtihad to reverse the subordination of women to men, which will leave its repercussions in producing a continuous feminist submission. (Kamla Bhasin-2003) Persecution also raises the issue of sovereignty on the other hand, so that men are singularly dominant over the submissive women. All these issues raised (oppression, injustice, dependency, sovereignty) raise a larger philosophical issue, which is the relationship between the selves like the relationship of the self and the other, these subjects that become another in relation to the corresponding self that It is at the same time another in relation to the other self, which, at the same time, raises the truth of the philosophy of difference through the relationship of the ego and the other philosophically, which both form a single community with a set of inherited customs and traditions that, later, become a culture that determines the relationship of the social roles that it performs. The two sexes, as they are roles motivated by a deep-rooted culture and not motivated by biology or elementary nature, this culture that will define social traditions as a rule is stronger than the power of laws now. A window that must be observed and submitted to its rulings, which makes men act arrogantly towards women to the point of oppression and control over them with a kind of violent behavior, and this confirms the saying that human behavior is shaped by culture and not by the natural facts that both male and female, which makes that culture that is The framework of social customs and values, the frame of reference establishing the issues of women's oppression and the continuation of their subordination and subordination under the dominance of men, to classify women in an inferior rank that confiscates their right to choose, unlike the man who derives his strength in the structure of the prevailing social system that qualifies him for supremacy in all institutions, starting with the family institution up to state institutions This means, the domination of a male culture that has produced a specific social engineering in which it is feared that women will be a true competitor to men in the public sphere.

Interpretive Islamic feminism called for the necessity of creating contemporary readings of religion that acknowledge the existence of women by combining universal moral perceptions and the highest human ideals of Islam, affirming that the duality of Islam and feminism does not contradict while providing the possibility of a correct reading of the religious text that will guarantee women their rights and protect them from the existing prevailing social considerations. Therefore, some feminists admit that some social and political facts that occurred in some Islamic societies have ended in results that were in the interest of women, such as the Islamic revolution in Iran, which transferred Iranian women from one state to 


\section{2nd Global Conference on Women's Studies}

10-12 June 2021

Berlin - Germany

another, and for this reason the feminism (Hala Afshar) believed that if Islam was achieved feminist slogans, it must be one of the doors of reconciliation with it, and there is no harm in that, so that (Ziba Mir Hosseini) would agree with her when she confirmed that the Islamic revolution carried something of freedom for women, meaning that it paved the way for a general feminist awareness.

\subsection{The human value system}

Which constituted basic axes from which the hermeneutical Islamic feminism was launched in establishing and establishing its issues in the defense of women and their stolen rights in the patriarchal society. This system almost includes the set of human values that God Almighty has approved for the human being (such as freedom, justice, and equality) and other legitimate rights, which are Islamic feminists consider their interpretation of their movement and demands as closely and clearly linked to the human being and his value without regard to his gender, and for this they did not object to the participation and contribution of men in their activities, based on the fact that the battle for the liberation of women and obtaining their legitimate rights and non-discrimination falls on the shoulders of both men and women, as it is a battle of liberation humanity is generally from of slavery.

Islamic feminists believe that "equality is one of the general goals and orientations of religion, and that the basis of the philosophy of religion is to spread equality between individuals and the most truthful evidence is equality between men and women." (Rida Motamasek-2013)Thus, the hermeneutical Islamic feminism confirms its struggle for equality between the sexes, acknowledging that Islam wants in fact to transcend The issue of discrimination on the basis of gender and that the Qur'an provides her with strong arguments that support her theses with the clarity which is that what was revealed as a religion of Islamic texts and teachings differed from the practices and customs of Muslims and from what the commentators and legislators interpreted, which made some view Islam as a religion that carries a lot of error, and this What was confirmed by (Omaima Abu Bakr) of the existence of intentional entrenchment of some concepts based on discrimination against women and the processes of reformulating them within the interpretive discourse draw attention to some of the methods used by commentators to avoid the commitment to equality and justice between the sexes, while at the same time they were producing an authoritarian and discriminatory discourse.(Omaima Abu Bakr-2012)

If the humanist feminist current focuses on the search for identity, the human rights, political and development trend wants to amend and correct the reality of women by granting them equal rights to men and improving their reality through a fair and equal distribution of opportunities for development, care and support, and that both currents complement one another, so the search for identity is an open path to The conscious mind and the mind need tools to achieve it. (Kaltham Al-Ghanim-2015), Through the definition of the meaning of Islamic feminism, which Tawhidi went to, as "the collection of methods and patterns of behavior related to gender justice and equality and framed by Islamic values" (Naira Tawhidi1996)).Islamic feminism emphasized the need for ideas ,laws and Legislations to express the rights of women and their active role in public life without marginalization, in order for the value of justice to be the most basic in obligations and laws as fairness for women. Therefore, (Ziba Mir Hosseini) searches for justice and equality as basic values in the Islamic human system, which directly related to the issue of the Right, which considers women the basis of it, emphasizing the coherence of these values and their approval by all jurists in the laws governing the relationship between the sexes and rights Both of each other focus on the reasons for treating women as second-class citizens in the books of jurisprudence, which made her 


\section{2nd Global Conference on Women's Studies}

10-12 June 2021

Berlin - Germany

believe that the justice of Islam is a goal that can only be realized at the present time through Islamic legislation entering the gates of democratization and filtering modernity, stressing that Islamic discourses of all their diversity need processes of reconciliation and compatibility with issues Human rights, especially women's rights, as the laws that Islamists impose in the name of Sharia are no longer a manifestation of Islamic justice. It is It is clear that Muslim women, since the first half of the twentieth century, have been unable to rely on external ideologies such as modernity, liberalism, democracy, or internal alternatives such as nationalism and anticolonialism in the struggle from In order to achieve gender equality, which made her stand before two options, namely: As for the Islamic religious identity, or the new gender awareness, but - in her opinion - this problem has disappeared with the end of the twentieth century, and rise of political Islam that helped to create a space in which Muslim women were able One who carried out reconciliation between her faith on the one hand and her struggle for gender equality on the other hand, and this was not the result of an egalitarian proposition presented by the Islamists in Gender relations, but their project (return to Sharia) and their endeavors to translate the theological ideas contained in Islamic law into political ideologies raised waves of criticism that included women's issues, and theoretical criticism soon turned into a movement on the other, and the number of women doubled who thought there was no contradiction between Islam and feminism. In addition the necessity of liberating the feminist discourse from all other discourses, and calling for a new feminist discourse in its aspirations and demands, Islamic in its language and sources of legitimacy, especially in light of the inequality inherent in Islamic law as human constructions that contradict the essence of divine justice itself.. (Ziba Mir Hosseini-2012) Hosseini also addressed the relationship between feminism and the Qur'anic texts ask, "Why do you not reflect the values of justice and equality in the laws governing the relationship between a man and a woman if they are two Qur'anic values?", and she believes that feminists absolve Islam of inequality and that there are human frameworks that explain the Qur'anic texts and that the task of Islamic feminists is to reveal the equal message and reveal The contradiction to social norms and the Islamic value, which is freedom. Hosseini also focused in her feminist discourse on three things).. (Ziba Mir Hosseini-2012): -

1- Islamic law, with its legal mechanisms, responds to social practices and human experiences that may deal with the demands of women.

2- Islamic law is still the preserve of male jurists, and it is imperative today to involve women in knowledge production processes.

3-That there is a theoretical consensus between Islam and the feminist search for justice, which makes the feminist project in Islam a source of concern for holders of traditional views of Islam.

Interpretive feminism also defines freedom as an intellectual basis based on its foundations, citing the freedom of opinion, belief and choice that Islam has agreed upon in two surahs: AlBaqarah - Verse - 256 and Surat Al-Muhtahna - Verse 11, which affirmed that women are free to hold public positions and the judiciary, and in the field of feminist political philosophy, It seeks only freedom, the abandonment of all restrictions based on gender differences between men and women, and the formation of new social and family systems. (Mohamed Legenhausen 2013)

The interpretation of Islamic feminism for its intellectual principles (justice, freedom, and equality) is nothing but a search through it for the political and social rights of women who have been stripped of patriarchal patriarchy in their society, and which they have tried to obtain through following approaches (interpretation, ijtihad, deduction, induction) For religious texts, 


\section{2nd Global Conference on Women's Studies}

10-12 June 2021

Berlin - Germany

which identified several ways to reinterpret them to arrive at the value system for women (justice, freedom, equality), the most important of which are: (Nourhan Abdel-Wahab-2016) 1- To cite Qur'anic verses that explicitly state the values of justice, equality and freedom between men and women.

2- Recalling and rehabilitating some Qur'an verses that are misinterpreted from the dominance of the male gaze.

3- Analyzing and deconstructing the Qur'anic verses that clarified the differences between men and women, and reinterpreting them in a non-discriminatory way.

And based on the Islamic feminism's emphasis on the existence of the sacred as a frame of reference, interpretive Islamic feminism presented the religious text as a basic starting point for it to arrive at its other intellectual principles represented in the system of values (justice, freedom and equality), where Islamic feminism derived its understanding of women's issues and their treatment of them through relying on basic Islamic sources to be a starting point and a primary cognitive reference for it, through which it demonstrated the error of the masculine reading of the religious text and the illegality of excluding women in public areas according to the use of the method of re-reading or interpretation of sacred religious texts, i.e. In other words, liberating the traditional religious view of women within the framework of the new religious understanding (Fahmi Al-Jadaan) .Islamic feminism relied on the Qur'an as a basic starting point and effective tool to defend women's rights and confront the hegemony of the patriarchy, in addition to addressing the discourse produced by successive commentators on issues related to gender. Some verses of the Noble Qur'an raised them to explore their cultural margins, so that the texts of their interpretations are considered sites of social and cultural formulation of gender, and they also have an impact on the formulation of social norms and awareness, and this is the reason for using this formula to legitimize cultural prejudices and unfair practices and attitudes towards women in Islamic societies. (Omaima Abu Bakr,) Islamic feminism also follows methods of reading and interpretation to enable it to re-read texts and even historical documents to extract and clarify the true role of women. The matter goes beyond the issue of confrontation between men and women, to where the search for a vision of the history of the human situation that includes both parties is not limited to masculinity only. (Hafnawi Baali,2009) With the existence of Islamic feminist intellectual and cultural qualifications worthy of the possibility of influence and influence, it is necessary for this research work from a specific methodological framework, and to unify the methodology used to establish feminist knowledge from an Islamic perspective, by following the classical methodologies, including the Ijtihad through which it seeks to verify religious sources And interpretation, in addition to the use of new linguistic methods and tools (language, history, analysis, literary criticism, sociology, and anthropology) order to emphasize the need to limit resort to an external literal understanding of the religious text, and to emphasize the restoration of the text in its historical context. For this reason, Al-Jadaan asserted that "the method of re-reading, interpretation, or interpretation is the approach that directs the issues and problems of And based on the Islamic feminism's emphasis on the existence of the sacred as a frame of reference, interpretive Islamic feminism presented the religious text as a basic starting point for it to arrive at its other intellectual principles represented in the system of values (justice, freedom and equality), where Islamic feminism derived its understanding of women's issues and their treatment of them through relying on basic Islamic sources to be a starting point and a primary cognitive reference for it, through which it demonstrated the error of the masculine reading of the religious text and the illegality of excluding women in public areas according to the use of the method of re-reading or interpretation of sacred religious texts, i.e. In other words, liberating 


\section{2nd Global Conference on Women's Studies}

10-12 June 2021

Berlin - Germany

the traditional religious view of women within the framework of the new religious understanding (Fahmi Jadaan-2010) .Islamic feminism relied on the Qur'an as a basic starting point and effective tool to defend women's rights and confront the hegemony of the patriarchy, in addition to addressing the discourse produced by successive commentators on issues related to gender. Some verses of the Noble Qur' an raised them to explore their cultural margins, so that the texts of their interpretations are considered sites of social and cultural formulation of gender, and they also have an impact on the formulation of social norms and awareness, and this is the reason for using this formula to legitimize cultural prejudices and unfair practices and attitudes towards women in Islamic societies. (Omaima Abu Bakr,) Islamic feminism also follows methods of reading and interpretation to enable it to re-read texts and even historical documents to extract and clarify the true role of women. The matter goes beyond the issue of confrontation between men and women, to where the search for a vision of the history of the human situation that includes both parties is not limited to masculinity only. (Hafnawi Baali,2009) With the existence of Islamic feminist intellectual and cultural qualifications worthy of the possibility of influence and influence, it is necessary for this research work from a specific methodological framework, and to unify the methodology used to establish feminist knowledge from an Islamic perspective, by following the classical methodologies, including the Ijtihad through which it seeks to verify religious sources And interpretation, in addition to the use of new linguistic methods and tools (language, history, analysis, literary criticism, sociology, and anthropology) order to emphasize the need to limit resort to an external literal understanding of the religious text, and to emphasize the restoration of the text in its historical context. For this reason, Al-Jadaan asserted that "the method of re- itself today and tomorrow.'(Fahmi Al-Jadaan-2010)) And this is what the feminist (tawhidi) acknowledged that the activity of Islamic feminists had been launched from a religious background or a tactical political situation aimed at providing a new reading of the religious text (Naira Tawhidi-1996), as long as the authority of men over women was mainly due to the conservative patriarchal culture that created, defended and worked to maintain sexual discrimination, the review of jurisprudence in the opinion of Islamic feminism, the practice of ijtihad, and the understanding and interpretation of the Qur'an text, It is necessary that women can do the same as men, because there is no religious text that prevents feminist jurisprudence and an attempt to re-read the religious and jurisprudential text from a feminist perspective.

We must mention here an important topic, which is that the feminist visions critical of the religious traditions in which the man occupies a central position and strive to provide a special reading of the Islamic sources, has been divided according to the source based on it, some of which focused on the hadith as a basic tool through which it seeks to provide a reading New, such as Moroccan Fatima Mernissi and Turkish Hedayat Toksal, while others focus and discuss exclusively in the Noble Qur'an as examples (Amina Wadud, Rifaat Hassan, Fatima Nassif) stating that "the Qur'an is more equitable in sex, while most of the unfair Islamic rulings on women derive their sources from the hadeth". "(Rifaat Hassan,2005) The book (The Qur'an and Women) (Amna Wadud Mohsen,2006) by Amina Wadud, published in 1999 as an indication of this, and she declared in her introduction that her exegetical methodology adheres to the traditional approach to interpreting the Qur'an With the Quran. In the field of reexamining the influence of religious sciences, interpretive Islamic feminists denounce the men's giving the hadiths equal weight to the Qur'anic verses, stressing that the issue of the primacy of the Qur'an over hadith is an issue that cannot tolerate discussion (Margaret Maryweather and Judith Tucker,2003). Islamic hermeneutical feminism also adopted new interpretations in order to reach radically different conclusions from those reached by 


\section{2nd Global Conference on Women's Studies}

traditional interpretations such as (Tafsir al-Tabari, al-Zamakhshari, al-Qurtubi, Ibn Kathir) which all established more gender-biased readings, concepts and ideas that developed "until they reached The stage of consolidation in Islamic reference studies, which made it one of the accepted ideas and assumptions that governed men's and women's understanding of gender roles and their mutual relations in Islam, which led to the prevalence of a strong belief that Islam endorses and prescribes it. "(Omaima Abu Bakr,2013) On the basis of this, hermeneutical Islamic feminism affirms that women have a right In re-reading the Qur'an and its interpretation .

Hermeneutics Islamic feminism does not ignore the cultural influence in the interpretation of some Quranic verses related to women's issues, based on the hypothesis of the influence of the cultural background of the interpreter, and the influence of the cultural practices surrounding him on this interpretation, and this means the influence of the beliefs, norms, traditions, practices and cultural values underlying the words and structures contained in the Quranic verses Which deals with issues related to women and forms the background for the interpreter. This confirms the problem of the interpreter's dependence on the cultural approach in interpreting the verses of the Noble Qur'an in general and in the interpretation of signs with issues of femininity in particular and their mechanisms. (Ahmed Sheikh Abdul Salam 2008).Accordingly, the interpretive Islamic feminism is protesting about that, and on the other hand, emphasizing the need to interpret texts by changing attitudes, drawing inspiration from Islamic law itself, and highlighting that the subject of prejudice and injustice towards women has been discussed in the name of religion. And clear texts from the Sunnah confirming the position of women and their partnership with men in humanity, taken through narrations and texts that have not been proven or suspected of being meaningful that justify the marginalization of women and viewing them inferior.(Hassan Saffar-2003). (Abu Bakr) asserts that despite the existence of 25 verses that establish the idea of equality in gender on religious, spiritual, social and political foundations, the tradition of interpretations has given great importance to only three of them. These verses produce interpretations that establish the inferior status of women and justify authoritarian structures absent from equality.(Omaima Abu Bakr-2013) So the chapter on women verse (34) (Men are the guardians of women because of each other's preference over one another and what they spent of their money). Some cite it as a religious text to highlight the man's personal preference over women and that it is below him, at a time when the interpretations show Modern feminism is the verse of guardianship as a verse related to the marital relationship, and that the man has established marital rights over the woman and is at the same time responsible for her care, protection and spending on her, and that he has the right to obey in their marital life according to Sharia guidelines, and then the man has nothing to do with her opinions, ideas, and even financial behavior. (Hassan Saffar-2003)) And this is what she says (Amina Wadud, Rifa'at Hassan, Aziza al-Habri, and Fatima Nassif) and others who represented the interpretive Islamic feminism, who considered that the intended meaning of guardianship here is spending on the home and the requirements of the family in return for a woman's pregnancy, breastfeeding and upbringing. It is this circumstance that deserves stewardship and is not permissible over time, as indicated by the traditional interpretations that have continuously linked the financial and marital responsibilities of the husband and the authority and influence in all other matters, both public and private. According to the guardianship verse, there are trends that do not approve women in exercising political rights, although there is a dividing line between (the guardianship of men) and (the independence of women). This limit is represented in matters related to the marital relationship. Guardianship, as all her actions are correct and do not need permission 


\section{2nd Global Conference on Women's Studies}

10-12 June 2021

Berlin - Germany

from a father or husband, whether they are financial actions or political rights. Therefore, the woman's particular problem is a socio-political problem and not a religious one. Islam has not deprived women from exercising their political rights and if the circumstances and customs inherited in the past It prevents women from using their political rights. (Khairy Abu Al-Azim Ferjani-2008) In addition to focusing some contemporary interpretations on the different social context, (Zainab Radwan) saw that the testimony of two women with one man was in the early days of Islam women were not literate and lacked extensive experience in complex financial transactions. Therefore, she saw no justification for literal application of this verse in the twenty-first century, which witnesses the presence of women with broad experiences in the field of transactions, accounting, trade, law and even politics, and for this the verse must be interpreted in new context, example, if the contemporary feminist interpretation focuses on verse 228 of Surah Al-Baqarah, then their interpretations have differed from one to another according to the different views and their reading even though they all fall into one point, which is that the Qur'an in this verse did not give an absolute preference to men over women. And raising it a degree from it and that it must be read according to the historical, social and economic contexts, time and place, and that it does not negate equality in rights between spouses, and that the differences between them do not result in a divine preference for one sex over the other.

\section{3- Position of Islamic thinkers on Islamic Feminism}

Islamic political thought was not the same in its view of women and their participation in the public sphere according to its sectarian divisions. Sunni jurisprudence was never a project to develop jurisprudence or to develop the opinion of jurists regarding the necessity of resuming jurisprudential production in a changed and different reality. In its most militant school, the Salafist current was an obstacle to women's political participation and obtaining the right to vote and be nominated, in contrast to Shiite jurisprudence, which was characterized by mobility when it linked the jurist to reality, and even linked political thought to jurisprudence that expressed political visions stemming from the jurist's attempt to transform the sacred text into reality. Through the use of methods of interpretation, interpretation, measurement and diligence.(Omaima Abu Bakr-2012), Shiite jurisprudence, unlike the Sunni (who was divided between reality and jurisprudential theory) was able in the twentieth century to accommodate a large part of the interpretations that affected the reality of women in the Islamic nation because it possessed within its jurisprudential and fundamentalist structure the components of this development through a group The rules related to the issue of Ijtihad in Shiite jurisprudence, until it produced an actual Ijtihad current that contributed to the development of jurisprudence in the same way that it contributed to the development of Status of women. Rather, the Shiite political thought dealt with the issue of women by placing it within its wider social context, when it made it part of a holistic conception of society (Azza Jalal Hashem,2007)By linking thought and jurisprudence together to be drivers of the movement in support of women's political participation, and this is what Azza Jalal addresses in her book (Iranian Women's Political Participation), in which she emphasized that the Iranian Revolution represents and embodies the strongest application of thought and jurisprudence related to women in the seventies, which continued until $2005 \mathrm{AD}$, which It is considered an opportunity to learn about the development of political thought related to women, and it actually creates this thought through the actual political practice of women, which was evident in the 1997 presidential elections with the victory of Khatami through women's support for the reform movement..In her book, she confirms that many Shiite jurists have concluded that social and 


\section{2nd Global Conference on Women's Studies}

political participation is an obligation on everyone, men and women, at a time when Sunni views alternate to determine the residency of women in The house raises the disadvantages of its public and political participation in particular. (Azza Jalal Hashem,2007)

The Shiite political thought does not stop there, but rather delves into the details of the reasons for the degradation of the status of women and their participation in the public sphere. For example, al-Subhani demonstrates the existence of dark spaces - as he put it - in the Islamic heritage towards women, and this means that there are perceptions from outside the text because The founding text of religious thought is unblemished towards women. As for the Islamic tradition, it has been subjected to behavior, so the modernists resorted to their own means to assess the correctness of the poor, to generate on its impact the science of wound and modification or the knowledge of men, and then it is necessary to look at its content and note the extent of its harmony with the spirit of Sharia and its primary purposes And with an unquestionable religious text. (Muhammad Taqi al-Sobhani-2009).

Shiite Islamic political thought also presents models that we can call feminists in terms of content when they called for long issues of women's liberation beyond even what Islamic feminists are demanding, such as Muhammad Hussain Fadlallah, Muhammad Mahdi Shams al-Din Ali Shariati, Mortada Mutahhari until Khatami, who was A reformist man in his thinking in terms of the issue of women, and Hassan Al-Saffar declares, "I hope for an original jurisprudential movement among the girls of Islam to play their role in manifesting the concepts of religion and disseminating its teachings and rulings in a modern modern language, and with a realistic scientific methodology, that we are waiting for the pious woman who writes a full cycle." (Hassan Saffar, (2003).In Islamic jurisprudence to discuss the issue of ijtihad between restriction and prohibition, that is, limiting it to men and prohibiting it from women, that "if a woman possesses the ability of diligence and deduction and confronts the discussion of issues and rulings related to them, within the established controls, her diagnosis may be deeper and more accurate in those issues." (Hassan Saffar-2003) He also says: "A woman is a man who is equal in his humanity, and shares with him in carrying out the role of the caliphate, and bears the responsibility of building the land, and God Almighty has given her as a man the grace of reason and the ability to perceive and know.'Rather, "a woman can reach the level of ijtihad by dealing with the legal text directly and devising concepts and rulings. Women can be a jurist and diligent and act according to her opinion and according to her own diligence."' (Hassan Saffar-2003)) Mr. Fadlallah explains that the modern view that interrogates the Qur'an and hadith objectively led to a positive change in the level of recognition of the humanity of women and their role in life because the understanding of the Qur'anic text in the past was affected by the prevailing social reality at the time, which was not far from the concepts of ignorance. The issue of women in contemporary times and strongly urged scholars to re-examine the text and study realit. He also affirms that the issue of referring to women in Sharia rulings is possible, so there is no objection to her being a mujtahid that is referred to her, if she possesses the competence that distinguishes her from men. (Muhammad Hussein Fadlallah-1996))،

\section{4- Conclusion}

The research on the subject of feminism in general and Islamic feminism in particular is an research in the power and authority which given to men according to the social and institutional structure, and it is attempts to restore the balance of power between the sexes and correct the imbalance in the gender balance of power in Arab Islamic societies. It is a critical trend that aims at liberation from patriarchal tendency and domination and all forms of concepts and 


\section{2nd Global Conference on Women's Studies}

10-12 June 2021

Berlin - Germany

beliefs that entrench any social organization on the basis of inequality and discrimination based on gender. Freedom, equality, justice and participation in the process of change.

Despite the novelty of the term Islamic feminism in the Islamic world, it is not new in its content and connotations, as Arab and non-Arab Islamic societies have witnessed the existence of an effective and prominent feminist role for a long time, not limited to the ninth decade of the twentieth century as a history of concern for the issue of women in its social aspects. Political, to become a more controversial topic between different intellectual and political currents.

The subject of feminism overlaps with many disciplines of knowledge (such as history, philosophy, politics, and sociology). Islamic feminism is serious research attempts to establish a feminist epistemology that emphasizes the necessity of eliminating injustice against women in general and their submission to the man who was entrenched by societal patriarchal norms and traditions, through traditional interpretations of sacred texts and prophetic hadiths. This led to the necessity of presenting new and alternative knowledge proposals for the inherited norms with a feminist vision, starting with defending women and restoring their stolen rights and freedoms in male societies, and the necessity of re-reading the religious text with new approaches far from the traditional visions and readings of it that established the issue of male domination over women to be Of his followers in the community.

Islamic feminism formed a defensive course of research critical of the traditional, popular and official legacies in the societies of the Arab and Islamic world, drawing attention to the need to take serious steps towards establishing and developing an Islamic feminist cognitive theory that supports women's issues based on its methodological tools by re-reading religious texts and investigating Islamic history, to present New feminist readings and interpretations refute traditional male-dominated interpretations that limit the role of women in being an active element in the march of human knowledge.

Islamic feminism is one of the most discussed intellectual trends, because it is serious research attempts on the necessity of granting a greater role to women in the public sphere by using the hermeneutic approach to re-read religious texts in order to base an Islamic feminist epistemology that advocates women's issues.

Multiple internal and external causes contributed to the emergence of the Islamic feminism movement based on cultural, social, ideological and political considerations, relying on a number of intellectual principles to consolidate its epistemology in defense of women's issues that were confiscated on discriminatory grounds, including the issue of persecution and subordination that women suffered in Its Islamic societies. For this reason, feminists have taken the religious text as a basis for them in the face of the domination of the patriarchal system in favor of defending women and their rights, by reintroducing a new interpretative reading that exposes the false traditional interpretations of women's rights.

We can be said that the subject of Islamic feminism will remain one of the most controversial topics among the various intellectual and political currents, especially when it started from specific intellectual issues with concepts of the current era such as (freedom, justice, equality), and which took a path and searched for their rights through it.

\section{References}

Ahmed Sheikh Abdul Salam (2008). Cultural Influence in Interpreting Female Qur'anic References, Journal of Contemporary Islamic Thought, Volume 13. 


\section{2nd Global Conference on Women's Studies}

10-12 June 2021

Berlin - Germany

Amani Saleh, (2000).Towards an Islamic Perspective on Feminist Knowledge, Journal of Women and Civilization, Issue 1, Cairo, Association for Women Studies and Civilization, $\operatorname{pp}(7-11)$.

Amani Saleh (2002, Vol. 3, October), The Gender Issue in the Qur'an: The Marital System between the Polarities of Sex and Guardianship, Cairo, Journal of Women and Civilization, pp.45-51.

Amal Garami, (2015). Islamic feminism: a new feminist movement or a feminist strategy for obtaining rights? In a group of researchers, Arab Feminism A Critical Vision, 2nd Edition, Beirut, Center for Arab Unity Studies, pp.360-375.

Asma Lamrabet, (2019) The Muslim Woman: Liberation and Belonging, Alliance or Struggle for Loyalty, translated by Bushra Ghazali. From http // WWW.asma.lamrabet.com.

Amna Wadud Mohsen,( 2006).The Qur'an and Women, translated by: Samia Adnan, Cairo, Madbouly Library.

Azza Jalal Hashem,( 2007).Iranian Women's Political Participation, Emirates Center for Strategic Studies and Research, Abu Dhabi.

Fahmi Jadaan, (2010).Outside the Squadron: A Study of Rejectionist Islamic Feminism and the Temptations of Freedom, Beirut, Arab Network for Research and Publishing.

Hassan Saffar, (2003).The Woman's Personality, Arab Cultural Center, Morocco.

Hafnawi Baali (2009) An Introduction to Feminist Criticism and Post-Feminist theory - A Reading in the Book of Feminist Genesis. Arabic Science Publishing, 1st edition, Beirut, Contribution of Difference, Algeria., No. 52, pp. 55-87.

Kaltham Al-Ghanim (2012). The intellectual frameworks and theoretical limitations of Arab feminist thought: an analytical view, in a group of researchers, Arab Feminism: A Critical Vision, 2nd edition, Beirut, Center for Arab Unity Studies, pp. 177-188.

Khairy Abu Al-Azim Ferjani, Women's Rights - A Comparative Study of Islamic Law and Contemporary Systems.

Kamla Bhasin,( 2003). Understanding Gender, Salem Center for Studies and Training in the Field of Women.

Mahdi Mahrizi, (2017) The Question of Women: Studies in the Renewal of Religious Thought in the Issue of Women, translated by Ali Al-Mousawi and others Beirut - Civilization Center for the development of Islamic Thought.

Margaret Maryweather and Judith Tucker (eds.),(2003)From the social history of women and gender in the modern Middle East, Edmund Burke III (export), Ahmed Ali Badawi (translation), Ahmed Zayed (review), Cairo, The National Project for Translation. 


\section{2nd Global Conference on Women's Studies}

10-12 June 2021

Berlin - Germany

Muhammad Legenhausen,(2013), Islam versus feminism, they meet in vision and goals, in a group of authors, Woman and her Issues, Comparative Studies between Feminism and Islamic Studies, Second Edition, Beirut, Civilization Center for the Development of Islamic Thought, pp. 65-97.

Muhammad Taqi al-Sobhani, (2009).The Comprehensive Model of the Character of the Muslim Woman .. Structures and Concepts, Civilization Center for the Development of Islamic Thought, Beirut.

Muhammad Hussein Fadlallah, (1996), The World of Women, Dialogue - Siham Hamia, prepared by Mona Blaybel, 4th Edition, Beirut, Dar Al Malak.

Naira Al-Tawhidi (1996) Feminism, Democracy and Islam, $1^{\text {st }}$ Edition, Los Angeles.

Ziba Mir Hosseini (2012), Islam, feminism, the cage, translated by: Ahmad Barakat. From http://alkabea.blogspot.com/2012/10/blog-post.html

Nourhan Abdel-Wahab,( 2016),Islamic Feminism: Problematics and Requirements of Reality, Believers Without Borders for Studies and Research, from https://www.mominoun.com.

Omaima Abu Bakr, (2012), A Gender-aware Reading of Interpretations of the Qur'an, in a group of researchers, Feminism and Religious Studies, Omaima Abu Bakr (Editor), translated by: Randa Abu Bakr, Cairo, Center for Women and Memory ., Pp. 269-288.

Omaima Abu Bakr, (2013 ).Feminist and Islamic Perspective - New Horizons for Knowledge and Reform, Cairo, Women and Memory Forum.

Rida Motamasek,(2013). Islamic Feminist Movement, Facts and Challenges, in a group of authors, Woman and her Issues, Comparative Studies between Feminism and Islamic Vision, Beirut, Civilization Center for the Development of Islamic Thought.pp.97-123.

Rifaat Hassan's statement (6/21/2005), Moataz Al-Khatib, Islamic Feminism and Male Rulings as an Explanatory Model, Al-Hayat Newspaper, Issue 15421, p.15.

Zaki Al-Milad, (2008). Islam and Women - Renewing Religious Thinking on the Issue of Women, Beirut, center for civilization for Islamic Development and Though. 